\title{
PENGGUNAAN BAKTERI ASAM LAKTAT DAN LEMAK SAPI DALAM PENGOLAHAN LIMBAH TUNA MENJADI SOSIS FERMENTASI
}

\author{
Diah Ikasari"), Syamdidi*), dan Theresia Dwi Suryaningrum*)
}

\begin{abstract}
ABSTRAK
Penelitian penggunaan bakteri asam laktat dan lemak sapi dalam pengolahan sosis fermentasi ikan tuna telah dilakukan. Tetelan daging tuna dan lemak sapi yang masing-masing telah halus dicampur dengan konsentrasi lemak sapi 10 dan $20 \%$ dari bahan baku. Adonan daging dan lemak kemudian diaduk dengan bumbu dan bakteri asam laktat. Terdapat 3 macam perlakuan bakteri yang digunakan yaitu Lactobacillus plantarum, Lactobacillus fermentum, dan campuran keduanya. Setelah tercampur secara merata, adonan kemudian dicetak dalam casing plastik dan disimpan pada suhu $25^{\circ} \mathrm{C}$ selama 24 jam. Setelah 24 jam, sosis dikeringkan dengan dehumidifier pada suhu $25^{\circ} \mathrm{C}$ selama 2 jam. Kemudian sosis difermentasi pada suhu ruang selama 24 jam dan selanjutnya dikukus selama 45 menit. Pengamatan yang dilakukan adalah analisis organoleptik, kandungan asam laktat, $\mathrm{pH}$, analisis mikrobiologi (ALT, coliform, jumlah bakteri asam laktat, dan E. coli) serta nilai gizi (kadar air, kadar abu, kadar lemak, dan kadar protein) produk sosis fermentasi. Hasil penelitian menunjukkan bahwa perlakuan penambahan lemak $20 \%$ menghasilkan produk sosis ikan tuna fermentasi dengan penampakan dan bau lebih baik, menyebabkan peningkatan kandungan asam laktat dan penurunan $\mathrm{pH}$ produk bila dibandingkan dengan penambahan lemak $10 \%$. Penggunaan jenis bakteri yang berbeda tidak berpengaruh pada nilai atribut dan tingkat kesukaan panelis, yaitu panelis menyatakan netral hingga agak suka terhadap produk sosis tuna fermentasi yang dihasilkan. Kandungan asam laktat yang diperoleh adalah $0,28-0,37 \%$ sedangkan $\mathrm{pH}$ sosis fermentasi yang diperoleh berkisar antara 5,28-6,02. Jumlah total bakteri pada sosis tuna fermentasi adalah log 2,53-3,33, sedangkan jumlah total bakteri asam laktat yang terkandung pada sosis tuna fermentasi adalah $\log 2,42-2,50$. Adapun jumlah coliform rata-rata pada semua perlakuan adalah $<3 \mathrm{MPN} / \mathrm{g}$ dan $E$. coli negatif, sedangkan kadar air sosis fermentasi yang dihasilkan adalah $54-58 \%$; kadar abu 3,54-3,85\%; kadar lemak 7,97-12,92\%; dan kadar protein 13,65-18,39\%.
\end{abstract}

KATAKUNCl: bakteri asam laktat, sosis fermentasi, limbah tuna

ABSTRACT: The use of lactic acid bacteria and beef fat in the processing of fermented sausage made of tuna waste. By: Diah Ikasari, Syamdidi and Theresia Dwi Suryaningrum

Research on the use of lactic acid bacteria and beef fat in the processing of fermented tuna sausage has been conducted. Minced tuna waste were mixed with 10 and $20 \%$ beef fat (concentration based on the amount of fish) and homogenized. The dough was mixed with lactic acid bacteria and spices. There were 3 bacteria treatments being used, those were Lactobacillus plantarum, Lactobacillus fermentum, and the mixture of both of them. After being homogenized, the dough was filled in plastic casing and conditioned at temperature of $25^{\circ} \mathrm{C}$ for 24 hours and dehumidified at $25^{\circ} \mathrm{C}$ for 2 hours. Sausage was fermented at room temperature for 24 hours followed by steaming for 45 minutes. Assessments were done on organoleptic properties, lactic acid content, $\mathrm{pH}$, microbiological load (TPC, coliform, total lactic acid bacteria, and E.coli) and also nutritive values (moisture, ash, fat and protein) of fermented sausage products. Results of experiment showed that addition of $20 \%$ beef fat resulted in the fermented sausage with better colour and odor than fermented sausage with addition of $10 \%$ beef fat. The use of different lactic acid bacterias did not significantly affect to the attribute and hedonic quality parameters, panelist ranged the product into neutral to slightly prefer. $\mathrm{pH}$ and lactic acid content of fermented sausage were $5.28-6.02$ and $0.28-0.37 \%$, respectively. The total plate count of fermented tuna sausage were $\log 2.53-3.33$, while the total lactic acid bacteria were $\log 2.42-2.50$. The average numbers of coliform of all treatments were less than $3 \mathrm{MPN} / \mathrm{g}$ and E.coli were negative, while the nutritive values of fermented sausage were moisture $54-58 \%$, ash $3.54-3.82 \%$, fat $7.97-12.92 \%$ and protein $13.65-18.39 \%$.

KEYWORDS: lactic acid bacteria, fermented sausage, tuna waste

7) Peneliti pada Balai Besar Penelitian dan Pengembangan Pengolahan Produk dan Bioteknologi Kelautan dan Perikanan, Balitbang KP, KKP; JI. KS. Tubun Petamburan VI, Slipi, Jakarta Pusat; E-mail: diah_ika263@yahoo.com 


\section{PENDAHULUAN}

Ikan tuna merupakan salah satu komoditas ekspor dan penghasil devisa dari sumber hayati perikanan Indonesia. Pada tahun 2008, nilai ekspor tuna menempati urutan ke dua setelah udang. Produksi tuna Indonesia mengalami peningkatan pada akhirakhir ini, yakni 176.996 ton pada tahun 2004 meningkat menjadi 183.144 ton pada tahun berikutnya dan tahun 2006 tercatat 159.404 ton, meningkat menjadi 191.558 ton tahun 2007. Total produksi tuna untuk ekspor tahun 2008 mencapai 130.056 ton senilai 347,189 juta dolar AS dan hingga Maret 2009 ekspor mencapai sekita: 24.101 ton senilai 64,017 juta dolar AS (Anon., 2009: $2009^{b}$

Ikan tuna yang biasa diekspor merupakan ikar bermutu tinggi, dan diolah menjadi produk beku seperi loin, chunk, dan steak. Dari pengolahan tersebu: dihasilkan tetelan daging tuna dan limbah tuna yang selama ini belum dimanfaatkan secara maksimal. Untuk kelompok ikan tuna, bagian ikan yang dapat dimakan (edible portion) berkisar antara 50-60\% dengan jumlah daging merah sekitar $1-2 \%$ (Anon., $2009^{c}$ ). Pemanfaatan daging dan tetelan ikan tuna yang tidak layak ekspor menjadi produk siap saji akan dapat meningkatkan nilai tambahnya. Salah satu produk yang dapat diolah dari daging tuna adalah sosis fermentasi. Sosis fermentasi merupakan salah satu produk makanan hasil fermentasi menggunakan bakteri asam laktat. Bakteri asam laktat berperan dalam melakukan penguraian glukosa atau karbohidrat menjadi monosakarida, protein menjadi asam amino, lemak menjadi asam lemak dan selanjutnya membentuk produk akhir yang berupa asam laktat dan senyawa lainnya (Fardiaz, 1992).

Bakteri yang telah banyak digunakan dalam pengolahan sosis fermentasi adalah Lactobacillus fermentum dan Lactobacillus plantarum (Buckle et al., 1987; Sholichah, 1995). Meskipun demikian kedua jenis bakteri asam laktat ini memiliki karakteristik yang berbeda sehingga menghasilkan produk sosis dengan karakteristik yang berbeda pula (Sholichah, 1995; Sudariastuty, 1997). Secara biokimia, L. plantarum diklasifikasikan sebagai bakteri homofermentatif, sedangkan L. fermentum diklasifikasikan sebagai bakteri heterofermentatif (Bridson, 1993). Golongan homofermentatif menghasilkan asam laktat lebih dari $85 \%$ sebagai hasil akhir, sedangkan heterofermentatif hanya menghasilkan sekitar $50 \%$ asam laktat. L. plantarum memiliki suhu optimum pertumbuhan 30 $35^{\circ} \mathrm{C}$, sedangkan L. fermentum memiliki suhu optimum $37^{\circ} \mathrm{C}$ (Frazier \& Westhoff, 1979). Bakteri heterofermentatif sangat penting untuk pembentukan aroma dan flavour karena terbentuknya senyawa asetaldehid dan diasetil, sedangkan bakteri homofermentatif lebih ke arah pembentukan tekstur (Jay, 1978). Penggunaan kultur campuran pada pembuatan sosis memberikan hasil yang lebih baik dibandingkan dengan penggunaan kultur sejenis, yaitu mempertahankan warna dan flavour (Wood, 1986). Berdasarkan hasil penelitian Indriati et al. (1994), suhu optimum untuk kultur campuran kedua jenis bakteri tersebut adalah $30^{\circ} \mathrm{C}$

Dalam pengolahan sosis fermentasi umumnya digunakan lemak untuk memperbaiki tekstur dar: aroma (Amano, 1965; Sholichah, 1995). Lemak sap: memiliki kelebihan bila dibandingkan dengan lemak nabati, yaitu banyak mengandung asam oleat (asam lemak tak jenuh tunggal) yang berpengaruh terhadar terbentuknva emulsi sosis sehingga tekstur yan dihasilkan lebih bagus. Hasil penelitian Indriani (1982 menyatakan penambahan lemak sapl dalam pembuatan sosis ikan tongkol memiliki penerimaar yang jauh lebih tinggi bila dibandingkan dengan bile menggunakan lemak nabati (minyak kelapa, minyak jagung, dan margarin). Selain itu jumlah lemak yang ditambahkan merupakan salah satu faktor yang menentukan daiam mendapatkan sosis ikan fermentasi yang lebih dapat diterima oleh konsumen (Irianto et al., 1994). Penambahan lemak tidak boleh lebih dari $30 \%$ dari berat ikan dan biasanya berkisar 5-30\% (Effie dalam Sholichah, 1995).

Tujuan dari penelitian ini adalah untuk mengetahui mutu sosis limbah tuna yang diolah dengan menggunakan bakteri asam laktat yang berbeda dan penambahan lemak sapi dalam jumlah yang berbeda.

\section{METODE}

\section{Bahan dan Alat}

Bahan yang digunakan dalam penelitian ini adalah tetelan ikan tuna yang diperoleh dari salah satu pabrik pengolahan tuna di Muara Baru, Jakarta. Sedangkan bakteri yang digunakan adalah $L$. plantarum, $L$. fermentum, dan campuran keduanya. Kultur bakteri diperoleh dari Laboratorium Veteriner Fakultas Kedokteran Hewan, IPB. Selain itu juga digunakan bahan lain yaitu : tepung tapioka $15 \%$, garam $2 \%$, bawang putih $4 \%$, lada $0,17 \%$, biji pala $0,2 \%$, ketumbar $0,17 \%$, cengkeh $0,1 \%$, gula halus $1,5 \%$, jahe $0,1 \%$, lesithin $0,8 \%$, dan flavour $1 \%$ (persentase dihitung berdasarkan bahan utama). Sedangkan lemak sapi yang digunakan dalam penelitian diperoleh dari pasar Palmerah, Jakarta. Jumlah lemak yang ditambahkan adalah 10 dan $20 \%$ dengan mengurangi jumlah ikan yang digunakan, jumlah total dari lemak dan ikan diasumsikan sebagai bahan utama. Komposisi bahan yang digunakan dalam pembuatan sosis fermentasi ikan tuna disajikan pada Tabel 1. 
Tabel 1. Komposisi bahan dalam pembuatan sosis fermentasi dari limbah tuna

Table 1. Ingredient of fermented sausage made of tuna waste

\begin{tabular}{lcc}
\hline \multicolumn{1}{c}{ Bahan/Ingredients } & $\begin{array}{c}\text { Perlakuan 1/ } \\
\text { Treatment 1 }\end{array}$ & $\begin{array}{c}\text { Perlakuan 2/ } \\
\text { Treatment 2 }\end{array}$ \\
\hline Bahan Utama/Main Ingredients : & & \\
Daging ikan/Fish flesh & $80.00 \%$ & $90.00 \%$ \\
Lemak sapi/Beef fat & $20.00 \%$ & $10.00 \%$ \\
Bahan Tam bahan/Additional Ingredients : & & \\
Tepung Tapioka/Tapioca flour & $15.00 \%$ & $15.00 \%$ \\
Garam/Salt & $2.00 \%$ & $2.00 \%$ \\
Bawang putih bubuk/Garlic powder & $4.00 \%$ & $4.00 \%$ \\
Lada putih bubuk/White pepper powder & $0.17 \%$ & $0.17 \%$ \\
Pala bubuk/Nutmeg powder & $0.20 \%$ & $0.20 \%$ \\
Ketumbar/Coriander & $0.17 \%$ & $0.17 \%$ \\
Cengkeh bubuk/Clove powder & $0.10 \%$ & $0.10 \%$ \\
Jahe bubuk/Ginger powder & $0.10 \%$ & $0.10 \%$ \\
Lecithin/Lechitin & $0.83 \%$ & $0.83 \%$ \\
Dextrose/Dextrose & $1.50 \%$ & $1.50 \%$ \\
Perisa asap bubuk/Smoke flavour powder & $1.00 \%$ & $1.00 \%$ \\
Bakteri asam laktat/Lactic acid bacteria (10 ${ }^{8}$ Cfu/mL) & $0.50 \%$ & $0.50 \%$ \\
\hline
\end{tabular}

Alat yang digunakan dalam penelitian ini berupa silent cutter, stuffer untuk memasukkan adonan sosis ke dalam casing, mixer, pengaduk, kompor, panci, timbangan, dan dehumidifier.

\section{Metode Kerja}

Tetelan daging tuna yang akan digunakan dalam penelitian dibersihkan dari kotoran seperti tulang dan kulit. Tetelan daging tuna kemudian digiling sampai halus, ditimbang sesuai formula dan dicampur dengan lemak menggunakan silent cutter. Sebelum digunakan lemak dicuci bersih kemudian digiling sampai halus. Adonan daging tetelan dan lemak kemudian diaduk dengan bumbu hingga homogen. Selanjutnya ke dalam masing-masing adonan ditambahkan perlakuan bakteri fermentasi dengan memipet media kultur bakteri sebanyak $0,5 \%(\mathrm{v} / \mathrm{b})$ dengan kepadatan $10^{8}$ $\mathrm{cfu} / \mathrm{mL}$ terhadap total bahan utama. Bakteri terlebih dulu dikultur pada media susu skim cair $10 \%$ hingga mencapai jumlah $10^{8} \mathrm{cfu} / \mathrm{mL}$. Ada 3 macam perlakuan bakteri yang dicobakan, yaitu bakteri $L$. plantarum, L. fermentum dan campuran keduanya dengan perbandingan $1: 1$. Setelah tercampur secara merata, adonan kemudian dimasukkan dalam casing plastik berdiameter $6 \mathrm{~cm}$ dengan panjang $20 \mathrm{~cm}$ dengan menggunakan stuffer. Terhadap adonan yang telah dimasukkan dalam casing lalu dilakukan conditioning pada suhu $25^{\circ} \mathrm{C}$ selama 24 jam. Setelah 24 jam, sosis dikeringkan dengan dehumidifier pada suhu $25^{\circ} \mathrm{C}$ selama 2 jam. Kemudian sosis difermentasi pada suhu ruang selama 24 jam dan selanjutnya dikukus selama 45 menit (Arief, 2000) (Gambar 1). Pengamatan dilakukan terhadap mutu organoleptik produk menggunakan uji pembedaan atribut (warna, bau, tekstur, dan rasa) serta uji kesukaan panelis terhadap produk sosis fermentasi (BSN, 2006 ${ }^{b}$ ). Uji pembedaan atribut dilakukan untuk mengetahui sifat-sifat produk yang spesifik, seperti warna, bau, tekstur, dan rasa, menggunakan skala $1-5$ dengan kriteria paling bagus pada nilai yang lebih tinggi, sedangkan uji mutu hedonik lebih ditekankan pada nilai kesukaan panelis menggunakan skala 1-7 dengan kriteria nilai (1) sangat tidak suka; (2) tidak suka; (3) agak tidak suka; (4) netral; (5) agak suka; (6) suka; dan (7) sangat suka (Sunarlim et al., 2007). Selain itu juga dilakukan pengamatan terhadap kandungan asam laktat, $\mathrm{pH}$ (AOAC, 2000), mutu mikrobiologi (ALT, coliform, E. coli, dan total bakteri asam laktat) (BSN, 2006 ; 2006 ${ }^{\mathrm{c}}$ ) serta nilai gizi sosis fermentasi (kadar air, kadar abu, kadar lemak, dan kadar protein).

Analisis data pengamatan dilakukan dengan analisis ragam yang didesain menurut Rancangan Acak Lengkap pola Faktorial dengan 3 kali ulangan yang dilanjutkan dengan uji Beda Nyata, sedangkan untuk data organoleptik dianalisis dengan menggunakan uji Kruskal Wallis dan dilanjutkan dengan Mean Whitney sebagai uji lanjutan (Gaspersz, 1994). 


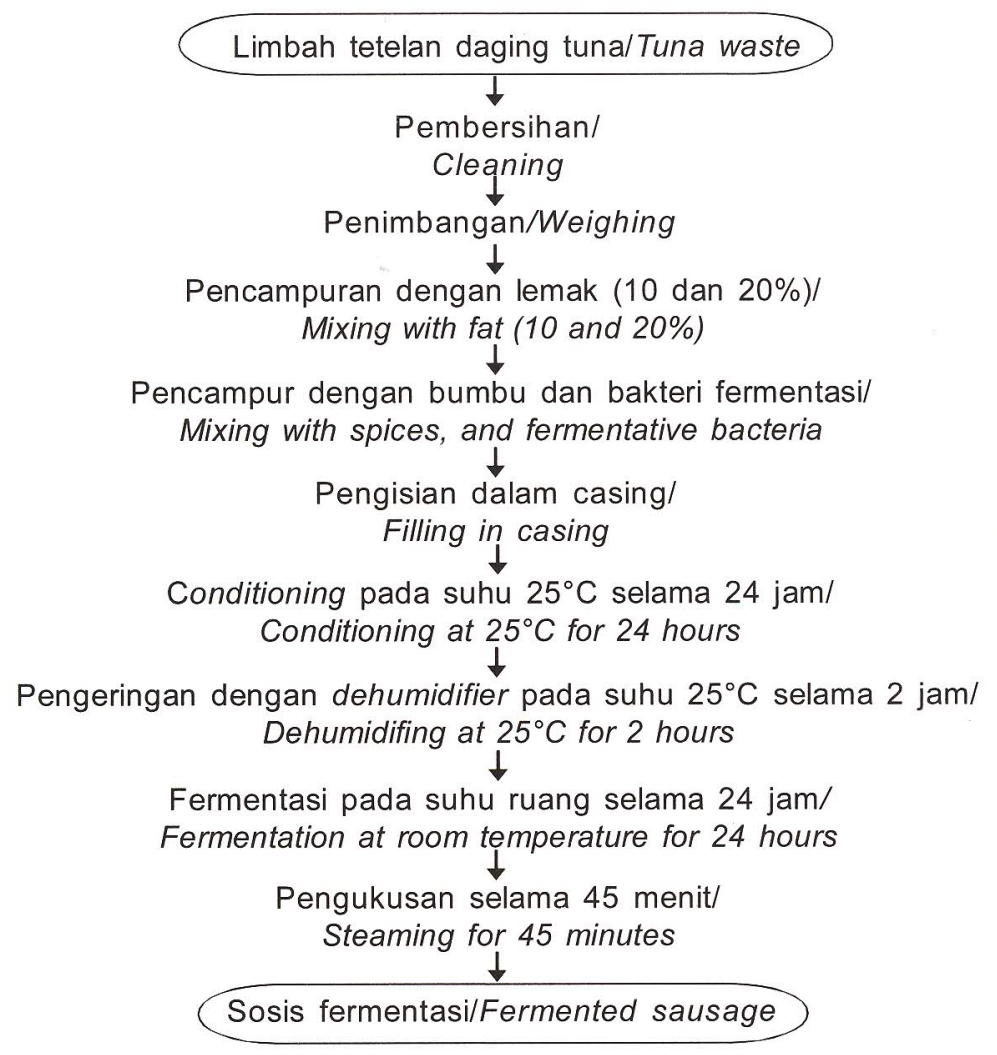

Gambar 1. Diagram alir pengolahan sosis fermentasi dari limbah ikan tuna (Arief, 2000 dimodifikasi).

Figure 1. Flow chart of fermented sausage processing of tuna waste (Arief, 2000 modified).

\section{HASIL DAN BAHASAN}

\section{Uji Organoleptik}

Uji organoleptik dilakukan terhadap 2 parameter, yaitu pembedaan atribut dan mutu hedonik. Hasil pengujian pembedaan atribut sosis fermentasi ikan tuna disajikan pada Gambar 2.

Hasil pengujian statistik terhadap hasil uji pembedaan atribut menunjukkan bahwa terdapat perbedaan yang nyata di antara perlakuan lemak untuk atribut warna dan bau $(p<0,05)$, sedangkan untuk perlakuan bakteri tidak berbeda nyata $(p>0,05)$. Panelis memberikan nilai yang lebih tinggi terhadap atribut warna dan bau produk yang menggunakan lemak $20 \%$ bila dibandingkan dengan lemak $10 \%$. Penambahan lemak dengan konsentrasi $20 \%$ membuat sosis lebih berwarna merah sehingga lebih menarik. Parameter bau juga menunjukkan pola yang sama. Penambahan lemak dengan konsentrasi lebih tinggi lebih memunculkan bau fermentasi. Hal ini karena lemak dapat menambah aroma yang lebih baik (Amano, 1965). Namun demikian jumlah lemak yang ditambahkan harus seimbang, karena penambahan lemak yang terlalu banyak akan mengakibatkan hasil sosis yang tidak enak dan keriput setelah pemasakan
(Effie dalam Sholichah, 1995). Menurut Pearson \& Gillet (1996), jumlah lemak yang ditambahkan tidak boleh lebih dari $30 \%$. Namun demikian, dalam hal penambahan lemak dan jenis bakteri tidak terlihat adanya perbedaan yang nyata pada atribut tekstur dan rasa menurut penilaian panelis $(p>0,05)$. Hal ini dimungkinkan karena pada sosis fermentasi rasa asam lebih dominan, sehingga rasa gurih yang dihasilkan tidak dapat dirasakan oleh panelis karena tertutupi oleh rasa asam tersebut.

Sedangkan hasil uji statistik terhadap hasil uji mutu hedonik menunjukkan bahwa secara keseluruhan tidak terdapat perbedaan yang nyata di antara perlakuan $(p>0,05)$. Panelis memberikan nilai 3,535,00 , yaitu netral hingga agak suka, terhadap warna, bau, tekstur, dan rasa produk sosis fermentasi. Hal ini mungkin karena tingkat kesukaan yang berbeda di antara panelis. Selama ini sosis fermentasi merupakan produk populer di mancanegara, khususnya Eropa, namun masih terbatas di pasaran domestik. Menurut Wood (1986), produksi dan konsumsi per kapita tertinggi adalah Itali, Spanyol, Perancis, dan Jerman yang memiliki tingkat konsumsi sekitar $7 \%$ dari total kebutuhan daging. Hasil uji mutu hedonik sosis ikan tuna fermentasi dari berbagai perlakuan disajikan pada Gambar 3. 


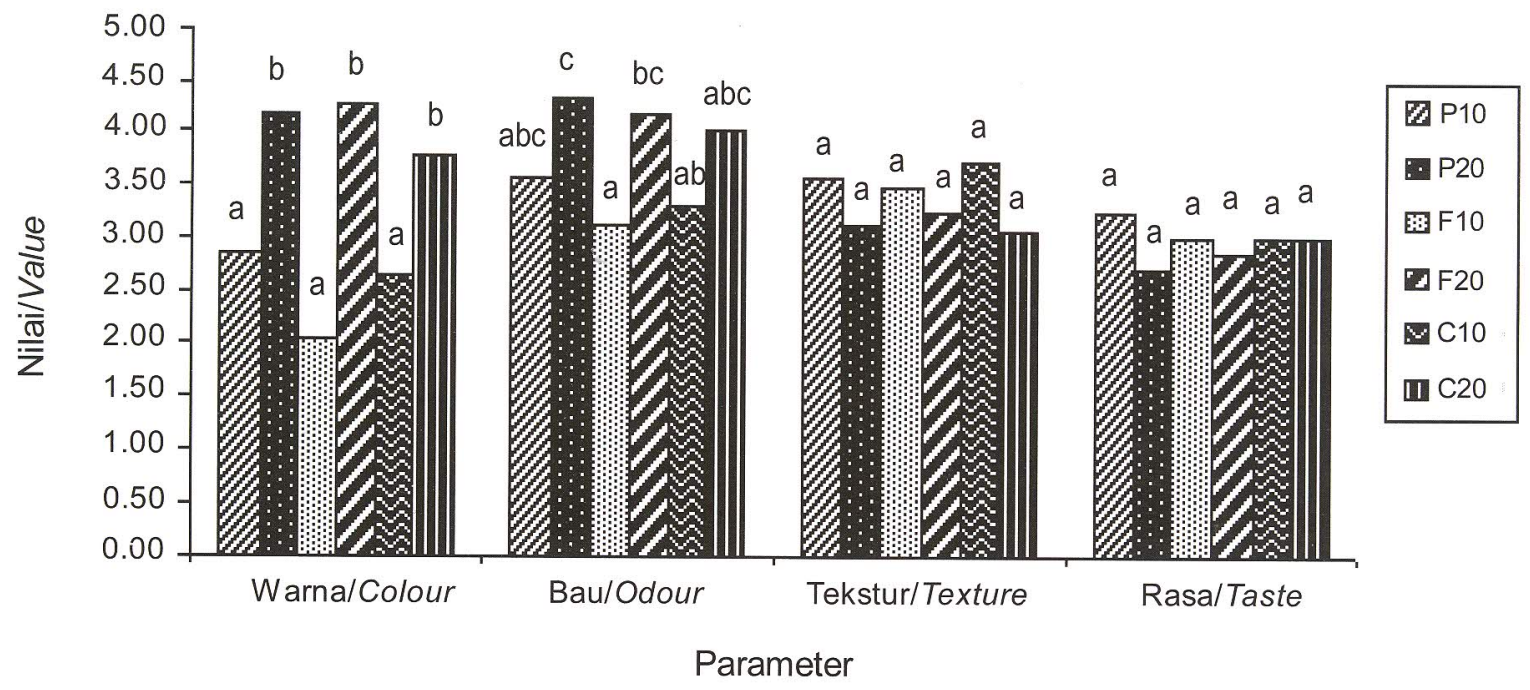

Keterangan/Notes :

P10 : L. plantarum, lemak 10\%/L. plantarum, fat $10 \%$

P20 : L. plantarum, lemak $20 \% /$ L. plantarum, fat $20 \%$

F10 : L. fermentum, lemak $10 \% /$ L. fermentum, fat $10 \%$

F20 : L. fermentum, lemak 20\%/L. fermentum, fat $20 \%$

C10 : Campuran L. plantarum dan L. fermentum, lemak 10\%/L. plantarum mixed with L. fermentum, fat 10\% C20 : Campuran L. plantarum dan L. fermentum, lemak 20\%/L. plantarum mixed with L. fermentum, fat $20 \%$

Gambar 2. Hasil uji pembedaan atribut sosis ikan tuna fermentasi dari berbagai perlakuan.

Figure 2. The result of atribute difference test of fermented tuna sausage of various treatments.

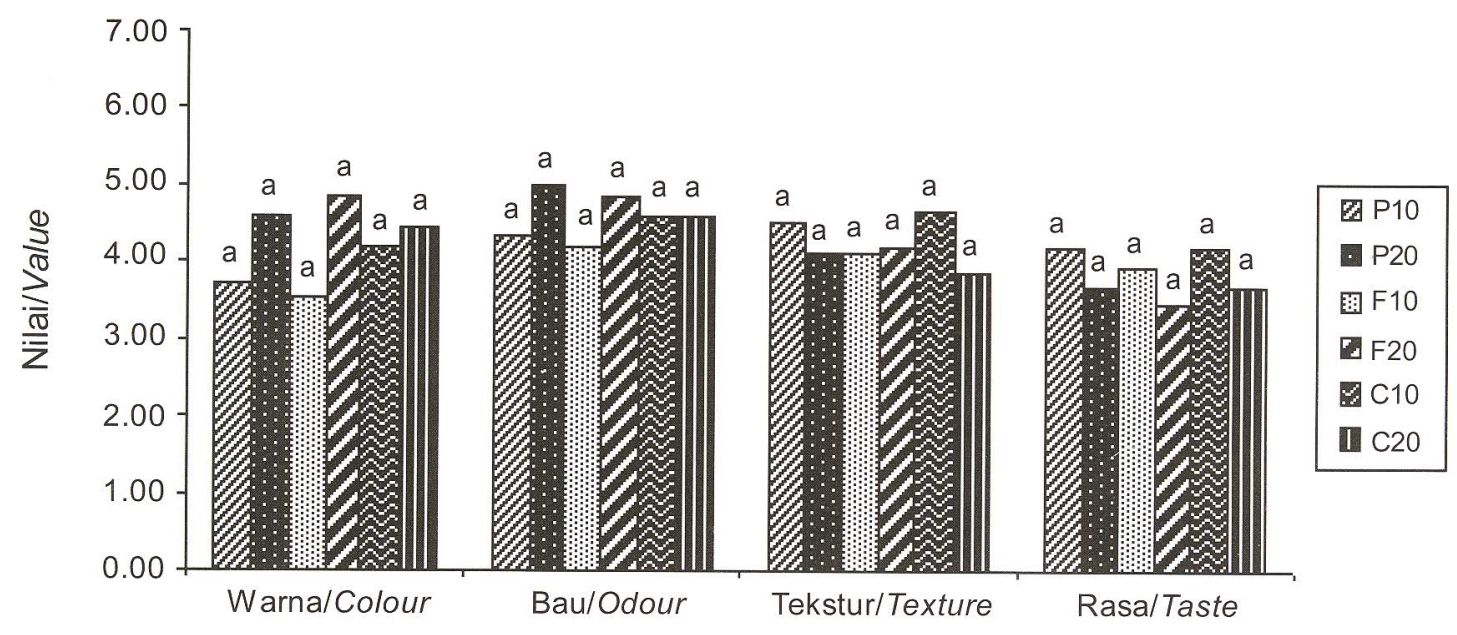

Keterangan/Notes:

Parameter

P10 : L. plantarum, lemak 10\%/L. plantarum, fat $10 \%$

P20 : L. plantarum, lemak 20\%/L. plantarum, fat $20 \%$

F10 : L. fermentum, lemak 10\%/L. fermentum, fat $10 \%$

F20 : L. fermentum, lemak $20 \% /$ L. fermentum, fat $20 \%$

C10 : Campuran L. plantarum dan L. fermentum, lemak 10\%/L. plantarum mixed with L. fermentum, fat $10 \%$ C20 : Campuran L. plantarum dan L. fermentum, lemak 20\%/L. plantarum mixed with L. fermentum, fat 20\%

Gambar 3. Hasil uji mutu hedonik sosis ikan tuna fermentasi dari berbagai perlakuan.

Figure 3. The result of hedonic quality test of fermented tuna sausage of various treatments. 


\section{Kandungan Asam Laktat}

Kandungan asam laktat sosis fermentasi ikan tuna pada berbagai perlakuan dapat dilihat pada Gambar 4.

Berdasarkan hasil uji statistik, terdapat perbedaan yang nyata di antara perlakuan penambahan lemak dan penggunaan bakteri yang berbeda $(p<0,05)$. Kandungan asam laktat yang diperoleh menunjukkan pola yang cenderung meningkat seiring dengan penambahan jumlah lemak yang ditambahkan. Nilai kandungan asam laktat paling tinggi diperoleh pada perlakuan penambahan lemak $20 \%$ dengan penggunaan bakteri campuran L. fermentum dan L. plantarum yaitu sebesar $0,37 \%$. Hal ini diduga karena campuran kedua jenis bakteri yang berbeda menimbulkan efek sinergisme atau saling mempengaruhi antar kedua jenis bakteri. Golongan homofermentatif (L. plantarum) menghasilkan asam laktat lebih dari $85 \%$ sebagai hasil akhir, sedangkan heterofermentatif ( $L$. fermentum) hanya menghasilkan sekitar 50\% asam laktat (Sholichah, 1995). Penggunaan kultur campuran pada pembuatan sosis memberikan hasil yang lebih asam dibandingkan dengan penggunaan kultur sejenis (Nurmi dalam Wood, 1986).

\section{$\mathrm{pH}$}

Nilai $\mathrm{pH}$ yang diperoleh pada penelitian ini berkisar antara 5,28-6,02. Terdapat perbedaan yang nyata di antara perlakuan penggunaan jenis bakteri asam laktat yang berbeda dan penambahan jumlah lemak pada sosis fermentasi ikan tuna $(p<0,05)$. Nilai $p H$ yang diperoleh menurun seiring dengan penambahan jumlah lemak. Hal ini sesuai dengan hasil yang didapatkan oleh Sholichah (1995), yang menyatakan nilai $\mathrm{pH}$ turun seiring dengan jumlah lemak sapi yang ditambahkan dalam sosis fermentasi ikan Jangilus. Selain itu asam laktat juga merupakan hasil akhir dari aktivitas bakteri asam laktat, sehingga dalam hal ini jenis bakteri berpengaruh terhadap nilai $\mathrm{pH}$ sosis fermentasi. L. plantarum merupakan bakteri homofermentatif yang menghasilkan asam laktat lebih tinggi bila dibandingkan dengan $L$. fermentum sehingga $\mathrm{pH}$ sosis yang dihasilkan pada perlakuan $L$. plantarum lebih rendah dibandingkan $L$. fermentum (Sholichah, 1995). Penggunaan kultur campuran pada pembuatan sosis juga menyebabkan penurunan $\mathrm{pH}$, sesuai dengan penelitian Nurmi dalam Wood (1986), yang menyatakan bahwa penggunaan kultur campuran yaitu kombinasi strain L. plantarum dan Micrococcus mengakibatkan penurunan $\mathrm{pH}$ yang lebih tajam serta mempertahankan warna dan flavour. Nilai pH sosis ikan tuna fermentasi dari berbagai perlakuan disajikan pada Gambar 5.

\section{Uji Mikrobiologi}

Hasil analisis mikrobiologi produk sosis fermentasi tuna dengan berbagai perlakuan dapat dilihat pada Tabel 2.

Jumlah total bakteri pada sosis fermentasi ikan tuna tidak berbeda nyata di antara perlakuan jenis

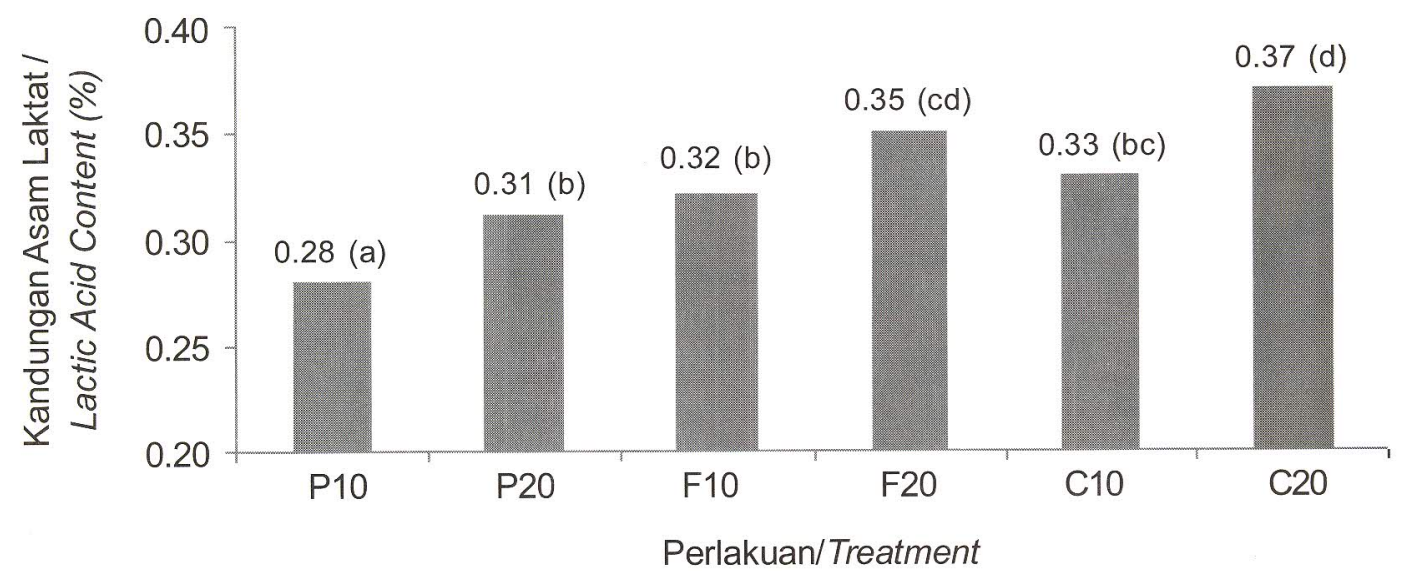

Keterangan/ Notes :

P10 : L. plantarum, lemak $10 \% /$ L. plantarum, fat $10 \%$

P20 : L. plantarum, lemak $20 \% / L$. plantarum, fat $20 \%$

F10 : L. fermentum, lemak $10 \% / L$. fermentum, fat $10 \%$

F20 : L. fermentum, lemak $20 \% / L$. fermentum, fat $20 \%$

C10 : Campuran L. plantarum dan L. fermentum, lemak 10\%/L. plantarum mixed with L. fermentum, fat $10 \%$

C20 : Campuran L. plantarum dan L. fermentum, lemak 20\%/L. plantarum mixed with L. fermentum, fat $20 \%$

Gambar 4. Kandungan asam laktat sosis ikan tuna fermentasi dari berbagai perlakuan.

Figure 4. Lactic acid content of fermented tuna sausage of various treatments. 


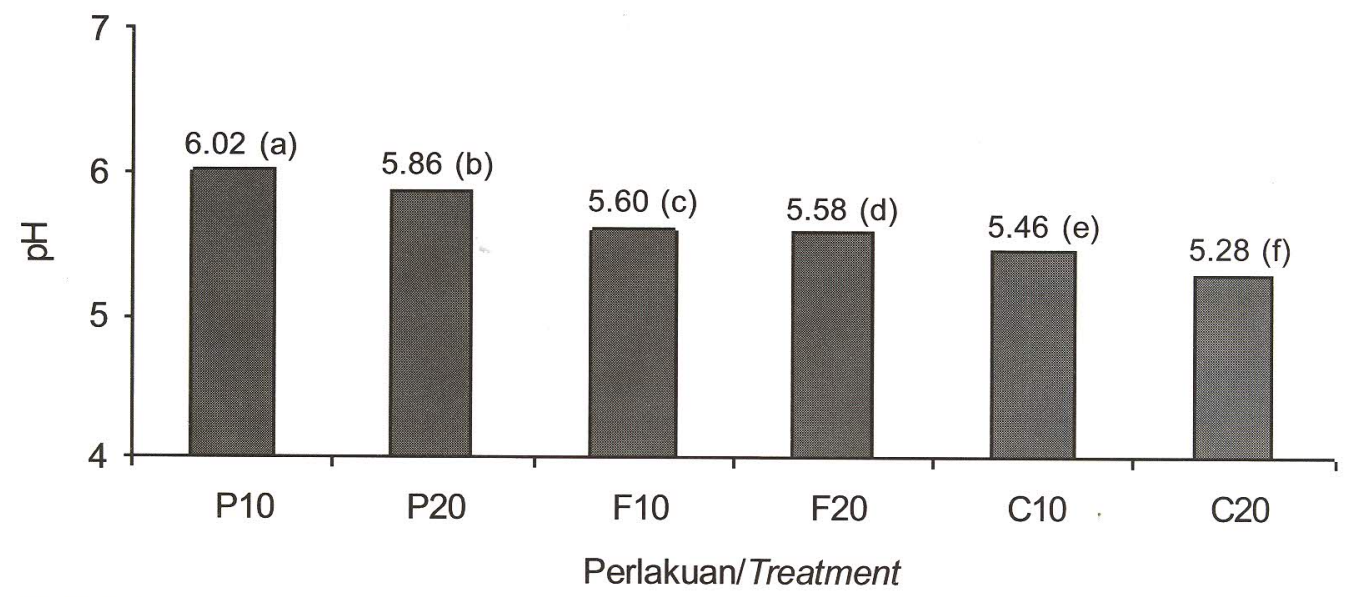

Keterangan/ Notes:

Perlakuan/Treatment

P10 : L. plantarum, lemak 10\%/L. plantarum, fat 10\%

P20 : L. plantarum, lemak 20\%/L. plantarum, fat $20 \%$

F10 : L. fermentum, lemak $10 \% /$ L. fermentum, fat $10 \%$

F20 : L. fermentum, lemak $20 \% /$ L. fermentum, fat $20 \%$

C10 : Campuran L. plantarum dan L. fermentum, lemak 10\%/L. plantarum mixed with L. fermentum, fat $10 \%$

C20 : Campuran L. plantarum dan L. fermentum, lemak 20\%/L. plantarum mixed with L. fermentum, fat $20 \%$

Gambar 5. Nilai $\mathrm{pH}$ sosis ikan tuna fermentasi dari berbagai perlakuan.

Figure 5. $\mathrm{pH}$ value of fermented tuna sausage of various treatments.

Tabel 2. Jumlah total bakteri, coliform, dan E. coli sosis ikan tuna fermentasi dari berbagai perlakuan Table 2. Total plate count, coliform and E. coli of fermented tuna sausage of various treatments

\begin{tabular}{ccccc}
\hline $\begin{array}{c}\text { Perlakuan/ } \\
\text { Treatments }\end{array}$ & $\begin{array}{c}\text { ALTI } \\
\text { TPC }(\text { Log) }\end{array}$ & $\begin{array}{c}\text { Coliform } \\
\text { (MPN/g) }\end{array}$ & E.coli & $\begin{array}{c}\text { Total Bakteri Asam Laktat/ } \\
\text { Total Lactic Acid Bacteria (Log) }\end{array}$ \\
\hline P10 & $3.12^{\mathrm{a}}$ & $<3.0$ & Negatif/Negative & $2.50^{\mathrm{a}}$ \\
P20 & $2.45^{\mathrm{a}}$ & $<3.0$ & Negatif/Negative & $2.42^{\mathrm{a}}$ \\
F10 & $3.33^{\mathrm{a}}$ & $<3.0$ & Negatif/Negative & $2.47^{\mathrm{a}}$ \\
F20 & $2.53^{\mathrm{a}}$ & $<3.0$ & Negatif/Negative & $2.44^{\mathrm{a}}$ \\
C10 & $2.75^{\mathrm{a}}$ & $<3.0$ & Negatif/Negative & $2.44^{\mathrm{a}}$ \\
C20 & $2.73^{\mathrm{a}}$ & $<3.0$ & Negatif/Negative & $2.45^{\mathrm{a}}$ \\
\hline
\end{tabular}

Keterangan/ Notes :

P10 : L. plantarum, lemak 10\%/L. plantarum, fat $10 \%$

P20 : L. plantarum, lemak 20\%/L. plantarum, fat $20 \%$

F10 : L. fermentum, lemak 10\%/L. fermentum, fat $10 \%$

F20 : L. fermentum, lemak $20 \% / L$. fermentum, fat $20 \%$

C10 : Campuran L. plantarum dan L. fermentum, lemak 10\%/L. plantarum mixed with L. fermentum, fat $10 \%$

C20 : Campuran L. plantarum dan L. fermentum, lemak 20\%/L. plantarum mixed with L. fermentum, fat $20 \%$

bakteri asam laktat maupun penambahan lemak sapi ( $p>0,05$ ), yaitu $\log 2,53-3,33$, masih lebih rendah bila dibandingkan dengan nilai standar yang ditetapkan dalam SNI 7388-2009 mengenai batas cemaran mikroba dalam pangan untuk kategori produk perikanan yang telah mengalami pengolahan yaitu 5 $\times 10^{5} \mathrm{cfu} / \mathrm{g}$ atau sama dengan $\log 5,69$ (BSN, 2009).

Demikian halnya dengan jumlah total bakteri asam laktat, menunjukkan hasil yang tidak berbeda nyata di antara perlakuan jenis bakteri asam laktat maupun penambahan lemak sapi $(p>0,05)$, yaitu log $2,42-2,50$.

Jumlah rata-rata coliform pada semua perlakuan adalah $<3 \mathrm{MPN} / \mathrm{g}$ sedangkan $E$. coli menunjukkan nilai negatif, sehingga diasumsikan produk sosis fermentasi tidak tercemar dan cukup bersih. Vuyst \& Vandamme (1994) menyatakan bahwa sinergi asamasam organik tertentu, misalnya asam asetat dan 
asam laktat yang dihasilkan oleh bakteri asam laktat akan menghambat pertumbuhan E. coli. Kisaran $\mathrm{pH}$ optimum pertumbuhan E. coliadalah 7,0-7,5 (Arief et al., 2008), sedangkan $\mathrm{pH}$ sosis fermentasi ikan tuna yang dihasilkan yaitu $5,28-6,02$, sehingga menyebabkan penghambatan pertumbuhan $E$. coli.

\section{Nilai Gizi Sosis Fermentasi}

Hasil pengamatan terhadap nilai gizi sosis fermentasi disajikan pada Tabel 3.

Kadar air produk sosis fermentasi ikan tuna berkisar $54-58 \%$. Hasil tersebut sesuai dengan pernyataan Tanikawa (1953) yang menyatakan bahwa kadar air untuk sosis ikan adalah sampai dengan $68,6 \%$. Kadar air pada perlakuan penambahan lemak $10 \%$ rata-rata menunjukkan hasil yang lebih tinggi bila dibandingkan dengan perlakuan penambahan lemak $20 \%$. Hal ini disebabkan karena dengan meningkatnya jumlah lemak yang ditambahkan maka emulsi sosis akan semakin padat. Hasil serupa ditunjukkan oleh Sholichah (1995) yang menyatakan bahwa penambahan lemak lebih tinggi pada sosis fermentasi ikan jangilus menyebabkan kadar airnya lebih rendah.

Nilai kadar abu sosis fermentasi ikan tuna yang diperoleh berkisar antara 3,54-3,85\%. Kadar abu pada dasarnya menyatakan kandungan mineral dalam suatu bahan. Mineral tersebut dapat berasal dari mineral alami yang terkandung dalam suatu bahan atau dapat berasal dari penambahan garam mineral yang terjadi selama proses pembuatan sosis (Pearson \& Gillet, 1996). Secara keseluruhan hasil kadar abu tersebut sesuai dengan hasil penelitian Quasem et al. (2009) bahwa kadar abu salami asap sekitar $3 \%$.
Kadar lemak sosis fermentasi ikan tuna yang dihasilkan 7,97-12,92\%. Kandungan lemak yang lebih tinggi diperoleh pada perlakuan penambahan lemak sebanyak $20 \%$ bila dibandingkan dengan perlakuan penambahan lemak $10 \%$. Hal ini sesuai dengan penelitian Huda et al. (2010) yang menyatakan bahwa kandungan lemak sosis dari daging bebek meningkat secara nyata dengan penambahan lemak berupa minyak. Lemak sapi merupakan bahan makanan yang mengandung $50,3 \%$ asam lemak jenuh seperti asam laurat, stearat, palmitat, dan miristat (Wardiatmo \& Ridwan, 1989; Raharjo, 1996). Penambahan lemak sapi akan meningkatkan kadar lemak sosis fermentasi. Sebaliknya, rata-rata kandungan protein pada sosis dengan perlakuan lemak $10 \%$ lebih tinggi dibandingkan dengan perlakuan penambahan lemak $20 \%$. Penambahan lemak dengan konsentrasi lebih tinggi menurunkan kandungan protein sosis, karena berkurangnya proporsi daging lumat ikan tuna sebagai sumber protein.

\section{KESIMPULAN}

1. Perlakuan penambahan lemak $20 \%$ menghasilkan produk sosis ikan tuna fermentasi dengan penampakan dan bau lebih baik, menyebabkan peningkatan kandungan asam laktat dan penurunan $\mathrm{pH}$ produk bila dibandingkan dengan penambahan lemak $10 \%$. Namun demikian kedua perlakuan masih menghasilkan tekstur yang agak kenyal hingga kenyal dan rasa kurang gurih.

2. Penggunaan jenis bakteri yang berbeda tidak berpengaruh pada nilai atribut dan tingkat kesukaan panelis, yaitu panelis menyatakan netral

Tabel 3. Nilai gizi sosis ikan tuna fermentasi dari berbagai perlakuan

Table 3. Nutrititive values of fermented tuna sausage of various treatments

\begin{tabular}{ccccc}
\hline Perlakuan/Treatments & $\begin{array}{c}\text { Kadar Air/ } \\
\text { Moisture Content } \\
(\%)\end{array}$ & $\begin{array}{c}\text { Kadar Abu/ } \\
\text { Ash Content } \\
(\%)\end{array}$ & $\begin{array}{c}\text { Kadar Protein/ } \\
\text { Protein Content } \\
(\%)\end{array}$ & $\begin{array}{c}\text { Kadar Lemak/ } \\
\text { Fat Content } \\
(\%)\end{array}$ \\
\hline P10 & 57.82 & 3.76 & 17.21 & 7.97 \\
P20 & 54.29 & 3.67 & 14.56 & 12.73 \\
F10 & 57.26 & 3.83 & 17.61 & 8.35 \\
F20 & 54.77 & 3.54 & 13.65 & 12.85 \\
C10 & 56.60 & 3.85 & 18.39 & 8.02 \\
C20 & 55.19 & 3.57 & 13.95 & 12.92 \\
\hline
\end{tabular}

Keterangan/ Notes:

P10 : L. plantarum, lemak 10\%/L. plantarum, fat $10 \%$

P20 : L. plantarum, lemak $20 \% / L$. plantarum, fat $20 \%$

F10 : L. fermentum, lemak $10 \% / L$. fermentum, fat $10 \%$

F20 : L. fermentum, lemak $20 \% / L$. fermentum, fat $20 \%$

C10 : Campuran L. plantarum dan L. fermentum, lemak 10\%/L. plantarum mixed with L. fermentum, fat $10 \%$

C20 : Campuran L. plantarum dan L. fermentum, lemak 20\%/L. plantarum mixed with L. fermentum, fat $20 \%$ 
hingga agak suka terhadap produk sosis tuna fermentasi netral hingga yang dihasilkan.

3. Nilai mutu mikrobiologi produk sosis fermentasi pada berbagai perlakuan masih lebih rendah dari batas cemaran mikroba pada produk pangan kategori perikanan, dengan jumlah total bakteri log $2,53-3,33$, jumlah total bakteri asam laktat log $2,42-2,50$, jumlah coliform rata-rata $<3 \mathrm{MPN} / \mathrm{g}$, dan E.coli negatif.

4. Nilai kadar air produk sosis fermentasi ikan tuna dengan perlakuan penambahan lemak dan jenis bakteri yang berbeda berkisar 54-58\%; nilai kadar abu 3,54-3,85\%; kadar lemak 7,97-12,92\%; dan kadar protein 13,65-18,39\%.

\section{DAFTAR PUSTAKA}

AOAC. 2000. Official Methods of Analysis of The Association of Official Analytical Chemist.Inc. Washington.DC

Amano, K. 1965. Fish sausage manufacturing. In Borgstrom, G. (ed.). Fish as Food. Academic Press, New York. 3: 265-279.

Anonim. 2009a. Indonesia ekspor tuna senilai 337,89 juta Dolar AS. www.kompas.com. Diakses pada tanggal 12 Nopember 2009.

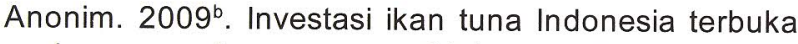
luas. www.kompas.com. Diakses pada tanggal 12 Nopember 2009.

Anonim. 2009c. Ikan tuna. http://abankerdi.blogspot.com/ 2009/12/ikan-tuna.html. Diakses pada tanggal 8 Nopember 2010.

Arief, I.I. 2000. Pengaruh Aplikasi Kultur Kering dengan Beberapa Kombinasi Mikroba terhadap Kualitas Fisiko-Kimia dan Mikrobiologi Sosis Fermentasi. Tesis. Program Pascasarjana, Institut Pertanian Bogor, Bogor. 104 pp.

Arief, I.I., Maheswari, R.R.A., Suryati, T., Komariah, dan Rahayu, S. 2008. Kualitas mikrobiologi sosis fermentasi daging sapi dan domba yang menggunakan kultur kering Lactobacillus plantarum 1B1 dengan umur yang berbeda. Media Peternakan. 31(1): 36-43.

Badan Standarisasi Nasional (BSN). 2006a. SNI 012332.3-2006. Cara Uji Mikrobiologi Bag. 3: Penentuan Angka Lempeng Total (ALT) pada Produk Perikanan.

Badan Standarisasi Nasional (BSN). 2006 ${ }^{\mathrm{b}}$. SNI $01-$ 2346-2006. Petunjuk Pengujian Organoleptik dan atau Sensori.

Badan Standarisasi Nasional (BSN). 2006 ${ }^{c}$ SNI $01-$ 2332.1-2006. Cara Uji Mikrobiologi Bag. 1: Penentuan Coliform dan Escherichia coli pada Produk Perikanan.

Badan Standarisasi Nasional (BSN). 2009. SNI 73882009. Batas Cemaran Mikroba dalam Pangan.

Bridson, E. 1993. The Oxoid Vade-Mecum of Microbiology. Unipath Ltd Basingstone, UK. p. 3234.
Buckle, K.A., Edwards, R.A., Fleet, G.H., and Wootton, M. 1987. Ilmu Pangan (H.P. Adiono, penerjemah). UI Press, Jakarta. $101 \mathrm{pp}$.

Fardiaz, S. 1992. Mikrobiologi Pangan. PT. Gramedia, Jakarta.

Frazier, W.C. and Westhoff, D.C. 1979. Food Microbiology Third Edition. Tata Mc. Graw Hill Publishing Company Limited. New Delhi.

Gaspersz, V. 1994. Metode Perancangan Percobaan. CV. Armico, Bandung.

Huda, N., Ismail, I., and Ahmad, R. 2010. Physicochemical properties of low-fat duck sausage formulated with palm oil. Asian Journal of Poultry Science. 4: 113-121.

Indriani, J. 1982. Penggunaan Berbagai Jenis Minyak dan Lemak dalam Pembuatan Sosis Ikan Tongkol. Skripsi. TPG. Fateta, IPB, Bogor.

Irianto, H.E., Indriaty, N., Haq, N., dan Saleh, M. 1994 Penentuan faktor-faktor penting di dalam pengolahan sosis ikan fermentasi. Jurnal Penelitian Pasca Panen Perikanan. 78: 43-51.

Indriati, N., Irianto, H.E., Haq, N., dan Suparno. 1994. Penentuan suhu inkubasi pada pembuatan sosis ikan fermentasi dengan menggunakan starter campuran. Jurnal Penelitian Pasca Panen Perikanan. 78: 66-71.

Jay, M.J. 1978. Modern Food Microbiology (2 ed). Van Nostrand. Reinhold. Company New York. 642 pp.

Pearson, A.M. and Gillet, T.A. 1996. Processed Meat. Chapman \& Hail. New York. 29 pp.

Quasem, J.M., Mazahreh, A.S., and Al-Shawabkeh, A.F. 2009. Nutritive value of seven varieties of meat products (sausage) producen in jordan. Pakistan Journal of Nutrition. 8(4): 332-334.

Rahardjo, S. 1996. Produk oksidasi lemak salah satu penyebab penyakit jantung koroner. Agritech. 15: 3135.

Sholichah, M. 1995. Pengaruh Penambahan Lemak Sapi dan Kultur Bakteri serta Lama Fermentasi terhadap Produk Sosis Fermentasi Ikan Jangilus (Istiophorus gladius). Skripsi. Jurusan Gizi Masyarakat dan Sumberdaya Keluarga, Fakultas Pertanian, Institut Pertanian Bogor, Bogor. 90 pp.

Sudariastuty, E. 1997. Pengaruh Suhu Inkubasi dan Bakteri Asam Laktat terhadap Perubahan Mutu Sosis Ikan Jangilus (Istiophorus gladius). Skripsi. Program Studi Teknologi Hasil Pertanian, Fakultas Perikanan dan IImu Kelautan, Institut Pertanian Bogor, Bogor.

Sunarlim, R., Setiyanto, H., dan Poeloengan, M. 2007. Pengaruh kombinasi starter bakteri Lactobacillus bulgaricus, Streptococcus thermophilus dan Lactobacillus plantarum terhadap sifat mutu susu fermentasi. Prosiding Seminar Nasional Teknologi Peternakan dan Veteriner. p. 270-278.

Tanikawa, E. 1953. Fish sausage and ham industry in Japan. In Mark, E.M. and Steward, G.F. (eds.). Advances In Food Research. Academic Press Inc. Publishers, New York. 4: 367. 
Vuyst, L.D. and Vandamme, E.J. 1994. Bacteriocins of Lactic Acid Bacteria: Microbiology, Genetics and Applications. Blackie Academic and Professional. London.

Wardiatmo, T. dan Ridwan, E. 1989. Peningkatan konsumsi lemak pada golongan ekonomi tinggi serta kaitannya dengan peningkatan penyakit jantung koroner. Medika. 10: 889-896.

Wood, B.J.B. 1986. Microbiology of Fermented Food (vol 2). Elsevier Applied Science Publishers. London and New York. 871 pp. 